\title{
Absorption and Metabolism Characteristics of Rutin in Caco-2 Cells
}

\author{
Xiaofang Zhang, ${ }^{1}$ Jinhui Song, ${ }^{2}$ Xiaopeng Shi, ${ }^{1}$ Shan Miao, ${ }^{3}$ Yan Li, ${ }^{1}$ and Aidong Wen ${ }^{1}$ \\ ${ }^{1}$ Department of Pharmacy, Xijing Hospital, Fourth Military Medical University, Xi'an, Shaan'xi 710032, China \\ ${ }^{2}$ Department of Otolaryngology, Shenyang 463 Hospital, Xiao He Yan Road 46, Shenyang, Liaoning 110042, China \\ ${ }^{3}$ School of Pharmacy, Institute of Materia Medica, Fourth Military Medical University, Xian, Shaan'xi 710032, China \\ Correspondence should be addressed to Jinhui Song; songjinhui@hotmail.com and Aidong Wen; aidongwen@hotmail.com
}

Received 17 July 2013; Accepted 25 August 2013

Academic Editors: M. Edery, S. E. Harris, R. B. Petersen, and M. Zarevucka

Copyright (C) 2013 Xiaofang Zhang et al. This is an open access article distributed under the Creative Commons Attribution License, which permits unrestricted use, distribution, and reproduction in any medium, provided the original work is properly cited.

\begin{abstract}
The intestinal absorption and metabolism characteristics of the potentially beneficial polyphenol rutin were studied by measuring the intracellular accumulation and transport of rutin into Caco-2 cells with the sensitive and reliable analytical method of HPLCcoupled tandem mass spectrometry. Rutin and glucuronidated rutin were absorbed differently by the basolateral and apical membranes, and rutin showed differential permeability through the apical and basolateral sides. Approximately $33 \%$ of the rutin was metabolized to glucuronidated rutin, and the intracellular concentration of glucuronidated rutin was much lower than that of parent rutin. P-glycoprotein and multidrug-resistant proteins 2 and 3 were involved in the transmembrane transport and intracellular accumulation of rutin by Caco- 2 cells. These results suggest that a specific transport system mediates rutin movement across the apical membrane in Caco- 2 cells and that metabolic enzymes are important for this process.
\end{abstract}

\section{Introduction}

Polyphenols are found in many plants and are abundant in fruits and vegetables $[1,2]$. These compounds have attracted much interest owing to clear evidence of their preventative effect in cardiovascular disease and cancer $[3,4]$. Rutin, a polyphenol, has received considerable attention as a potential protector against a variety of human diseases. Recent studies have summarized the mechanisms of rutin bioactivity [5-7].

Although rutin has received much attention owing to its multiple biological effects, the limited understanding of its absorption characteristics and metabolic pathways makes it difficult to understand the reasons for its poor bioavailability. In previous reports, intestinal metabolic enzymes, transporters, and even microflora were reported to be the main reasons for the poor bioavailability of natural polyphenols $[8,9]$.

Intestinal transport proteins, such as P-glycoprotein (P$\mathrm{gp})$, multidrug-resistant proteins (MRPs), and sodium glucose cotransporters, play key roles in drug transport and accumulation in human intestinal cells [10-12]. P-gp is highly expressed in the cell membrane, belongs to the ATPbinding cassette $(\mathrm{ABC})$ transporter superfamily, and has two nucleotide-binding domains and two halves that each are highly similar to other proteins; each half contains a transmembrane domain [13]. Naturally derived drugs make up a high proportion of P-gp substrates [14]. Although MRPs also belong to the $\mathrm{ABC}$ transporter superfamily, they have different substrate specificities than P-gp and can induce multidrug resistance [15]. These transporters are constitutively expressed and abundant in the apical membrane of many epithelial and endothelial barriers [16].

Recently, the human colon adenocarcinoma cell line Caco-2 was used to investigate and evaluate the role of the intestine in drug absorption, transport, and even metabolism $[17,18]$. When cultured in an appropriate medium, this cell line can spontaneously differentiate into polarized cells having many enterocyte-like properties of transport-related epithelia [19]. Various transporters such as P-gp and MRPs, which clearly participate in the intestinal transport mechanism and absorption characteristics of certain compounds, are expressed in Caco- 2 cells [20, 21]. In addition, cytochrome 
P450 and UDP-glucuronosyltransferase are expressed in Caco-2 cells [22], and thus this model has been widely used to study the characteristics of drug metabolism in the intestine.

In addition, although many studies have examined the biological effects of rutin, few studies have examined the absorption and metabolism of rutin, in particular, the intestinal characteristics of such processes. Thus, in the current study we used human Caco-2 cells and HPLC-coupled tandem mass spectrometry (MS/MS) to investigate rutin absorption and metabolism. We evaluated the underlying mechanism by analyzing the related cellular transporters and enzymes involved in these processes.

\section{Materials and Methods}

2.1. Chemicals. Rutin and emodin of the highest purity available ( $98 \%$, as determined by HPLC) were purchased from the National Institute for the Control of Pharmaceutical and Biological Products (Beijing, China). Verapamil, MK 571, and cyclosporine were obtained from Sigma (St. Louis, MO, USA). All chemicals and reagents used were of analytical or HPLC grade.

2.2. Cell Culture. Caco-2 cells were obtained from the American Type Culture Collection (Manassas, VA, USA) and maintained in plastic culture flasks (Corning Costar, Cambridge, MA, USA). Cells were cultured in Dulbecco's modified Eagle's medium (DMEM), medium supplemented with $1 \%$ nonessential amino acids, $1 \%$ L-glutamine, $20 \%$ fetal bovine serum, $100 \mathrm{U} / \mathrm{mL}$ penicillin, and $0.1 \mathrm{mg} / \mathrm{mL}$ streptomycin, and were grown in a humidified atmosphere of 5\% $\mathrm{CO}_{2}$ in air at $37^{\circ} \mathrm{C}[23]$. The cells were subcultured when they reached $80 \%$ confluency.

2.3. Cellular Uptake Studies. To test the characteristics of intracellular uptake of rutin using a published method [24], Caco- 2 cells were seeded at a cell density of $6 \times 10^{5}$ cells $\cdot \mathrm{cm}^{-2}$ on six-well plastic plates. Fresh culture medium was added $24 \mathrm{~h}$ before the uptake experiments. One hour before the uptake experiments, cells were preincubated at $37^{\circ} \mathrm{C}$ in incubation medium including modified Hank's balanced salt solution (HBSS; $137 \mathrm{mM} \mathrm{NaCl}, 5.4 \mathrm{mM} \mathrm{KCl}, 1.3 \mathrm{mM} \mathrm{CaCl}$, $0.8 \mathrm{mM} \mathrm{MgCl}_{2}, 0.4 \mathrm{mM} \mathrm{KH_{2 }} \mathrm{PO}_{4}, 0.3 \mathrm{mM} \mathrm{NaH} \mathrm{PO}_{4}$, and $10 \mathrm{mM}$ HEPES/Tris, $\mathrm{pH}$ 7.4). After removal of the incubation medium, different concentrations (from 5 to $200 \mu \mathrm{M}$ ) of rutin were added to the medium for different times (from $10 \mathrm{~min}$ to $6 \mathrm{~h}$ ) in the presence or absence of a transporter inhibitor, such as the P-gp inhibitor verapamil, the MRP2selective inhibitor cyclosporine, or the MRP inhibitor MK 571. To determine the intracellular concentration of rutin at the end of the incubation period, cell lysates were obtained by freeze-thawing the drug-containing cells in liquid nitrogen for three cycles. Samples were analyzed for rutin metabolites after treatment with $\beta$-glucuronidase [25].

2.4. Cellular Transport Studies. To measure rutin transport into Caco- 2 cells, the cells were seeded at a density of $1 \times$ $10^{5}$ cells $\mathrm{cm}^{-2}$ on Millicell Cell Culture Inserts (Millipore,
Billerica, MA, USA). Once the transepithelial electrical resistance value reached more than $300 \Omega \cdot \mathrm{cm}^{-2}$ (about 19 to 21 days after seeding), the cells were incubated with fresh medium and used for transport experiments [26]. Rutin was added from the apical (AP) or basolateral (BL) side to evaluate the transport characteristics of rutin into the cells in the presence or absence of the different inhibitors mentioned above. Samples were collected and analyzed with the methods described below.

2.5. Sample Preparation and Quantitative Analysis. A sensitive and high-efficiency method was developed to investigate the changes in rutin and its metabolites transported into Caco- 2 cells. Briefly, samples from cellular absorption or transport studies $(0.2 \mathrm{~mL})$ were extracted three times with $1 \mathrm{~mL}$ ethyl acetate with vigorous vortex mixing. After centrifugation $(3000 \times \mathrm{g})$ for $10 \mathrm{~min}$, the supernatants were reconstituted in $50 \mu \mathrm{L}$ acetonitrile and evaporated to dryness under $\mathrm{N}_{2}$. Rutin and its derivatives were quantified with liquid chromatography-MS/MS with the multiple reaction monitoring model [27].

A Quattro Premier system operating with MassLynx MS software, v4.1 (Waters Corporation, Milford, MA, USA) with electrospray ionization MS/MS to generate negative ions $[\mathrm{M}-\mathrm{H}]^{-}$was used. Collision-induced dissociation was achieved using argon as the collision gas. A reverse-phase HPLC system (Symmetry $\mathrm{C}_{18}$ column, $50 \times 2.1 \mathrm{~mm}, 5 \mu \mathrm{m}$. Waters Corp., Milford, MA, USA) was used to separate the compound with an isocratic mobile phase of $0.1 \%$ acetic acid/acetonitrile $(20: 80, \mathrm{v} / \mathrm{v})$. The column temperature was $25^{\circ} \mathrm{C}$, and the flow rate was $0.2 \mathrm{~mL} / \mathrm{min}$. Using the Bradford method with bovine serum albumin as the standard, total cellular protein concentrations were determined to normalize the intracellular drug concentration between experiments.

2.6. Data Analysis. Student's $t$-test was used for statistical analysis, and $P$ values $<0.05$ were considered significant.

\section{Results}

3.1. Method Development. To optimize the detection conditions, a standard rutin solution $\left(1 \mu \mathrm{g} \cdot \mathrm{mL}^{-1}\right)$ was used in the mobile phase. Parent ions and product ions of rutin were selected from spectra after standard solutions were injected into a mass spectrometer in electrospray ionization (ESI) negative-ion mode $[\mathrm{M}-\mathrm{H}]^{-}$. Using the most sensitive conditions for quantification, the parent ions of rutin were at $\mathrm{m} / z 609.4$, and the product ions were obtained at $\mathrm{m} / z 300.4$ (argon was the collision gas). For emodin (IS), the parent and product ions were at $\mathrm{m} / z 269$ and $\mathrm{m} / z 225$, respectively. The multiple reaction monitoring mass transition of rutin was at $\mathrm{m} / z 609.4 \rightarrow 300.4$ with a cone voltage of $40 \mathrm{~V}$ and collision energy of $32 \mathrm{eV}$. The transition of IS was at $\mathrm{m} / z 269 \rightarrow 225$ with a cone voltage of $40 \mathrm{~V}$ and collision energy of $33 \mathrm{eV}$ (Figure 1). In addition, the chromatographic conditions (Figure 2) were also optimized with retention times of 2.25 and $2.85 \mathrm{~min}$ for rutin and IS (emodin), respectively. The specificity of the extraction method and linearity were evaluated in 


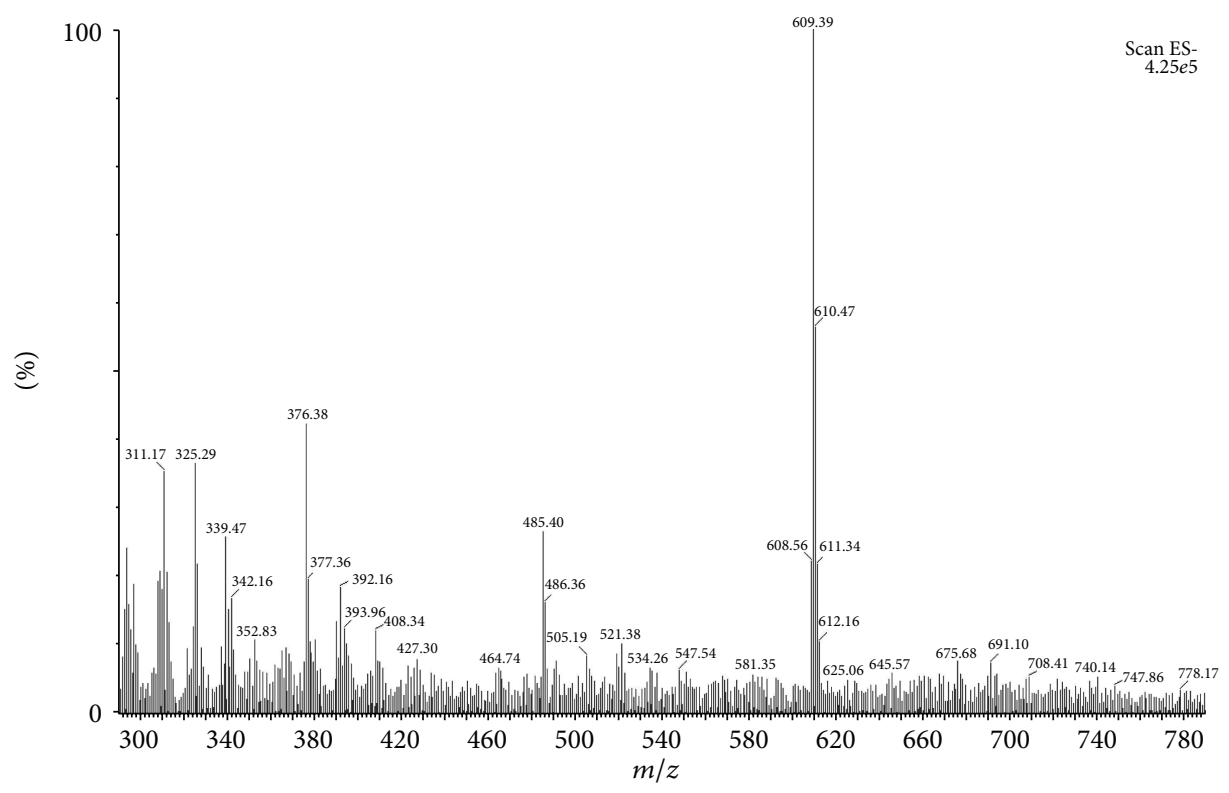

(a)

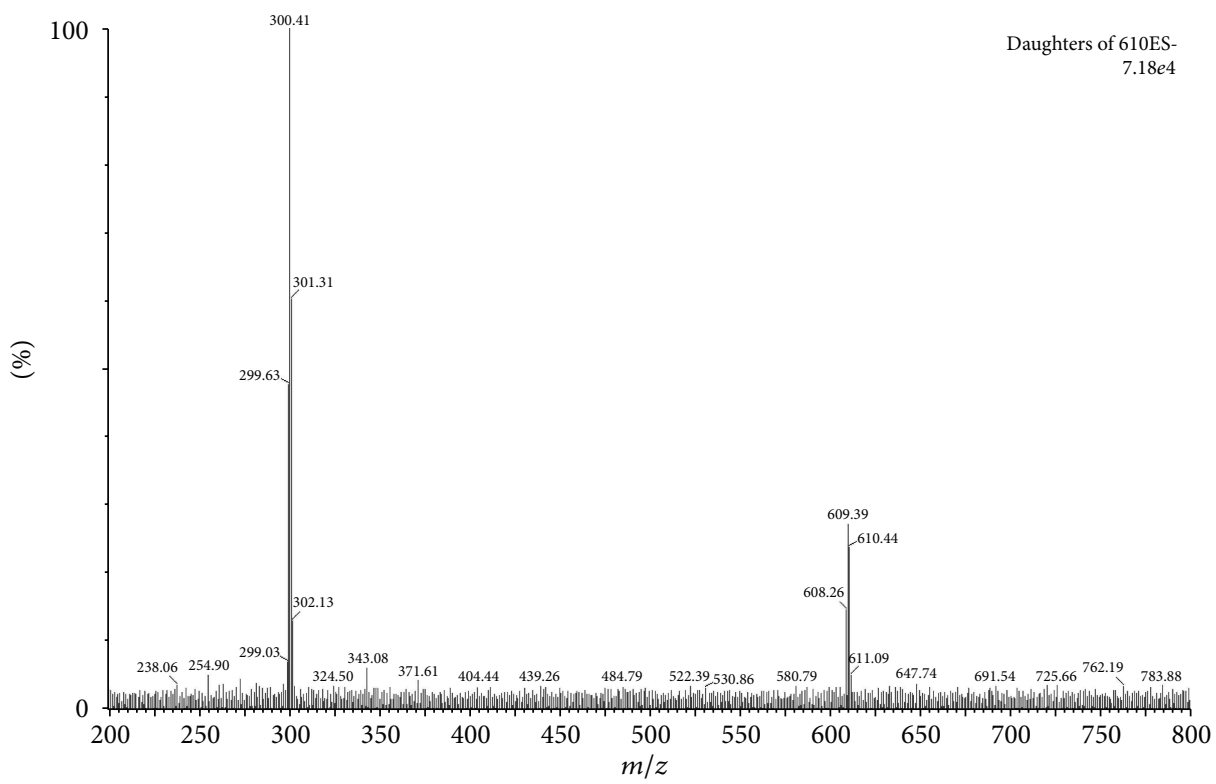

(b)

FIGURE 1: Mass precursor/product ion mass spectra of rutin. The parent ions of rutin were at $\mathrm{m} / \mathrm{z} 609.4$ (a), and the product ions of rutin were obtained at $\mathrm{m} / z 300.4$ (b). The multiple reaction monitoring mass transition of rutin was at $\mathrm{m} / z 609.4 \rightarrow 300.4$ with a cone voltage of $40 \mathrm{~V}$ and collision energy of $32 \mathrm{eV}$.

the experiments described below. The regression equation for the standard curve was as follows: $y=0.9251 x-0.024$ $\left(r^{2} \geq 0.9983, n=6\right)$ with the range of $1.0-200.0 \mathrm{ng} \cdot \mathrm{mL}^{-1}$. The lower limit of quantification (LLOQ), which was defined as the lowest qualification concentration, was $0.5 \mathrm{ng} \cdot \mathrm{mL}^{-1}$ at a signal-to-noise ratio $>10$.

3.2. Intracellular Characteristics of Rutin Absorption by Caco2 Cells. Previous reports have shown that polyphenol compounds can be absorbed rapidly by Caco-2 cells [28]. Thus, to investigate the intracellular characteristics of rutin absorption by Caco-2 cells, different concentrations of rutin were incubated with Caco-2 cells for different times (Figure 3). The intracellular accumulation of rutin increased steadily over $6 \mathrm{~h}$ (Figure 3(a)). After $2 \mathrm{~h}$ of incubation, the concentration had increased about 2.5 -fold compared with the first $10 \mathrm{~min}$ $(43.35 \pm 2.25$ versus $109.61 \pm 4.81 \mathrm{nmol} / \mathrm{L} \cdot \mathrm{mg}$.protein, $P<$ $0.05, n=7)$. We also examined different concentrations of rutin and observed absorption in a dose-dependent manner from 5 to $200 \mu \mathrm{M}$ (Figure 3(b)). The intracellular concentration increased more than 10 -fold $(13.35 \pm 3.18$ versus $147.73 \pm 6.69 \mathrm{nmol} / \mathrm{L} \cdot \mathrm{mg}$.protein, $P<0.01, n=7)$. In addition, we examined rutin metabolites in Caco-2 cells and detected changes in glucuronidated rutin after enzymatic 


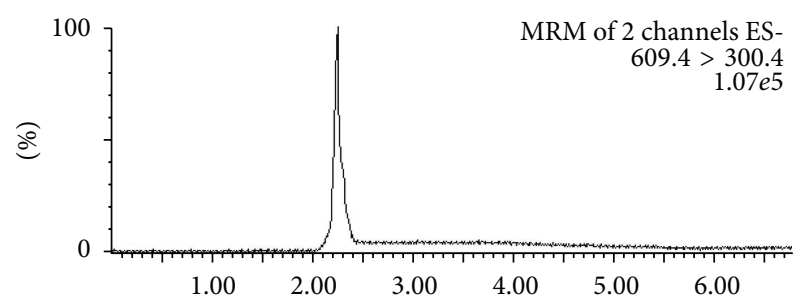

(a)

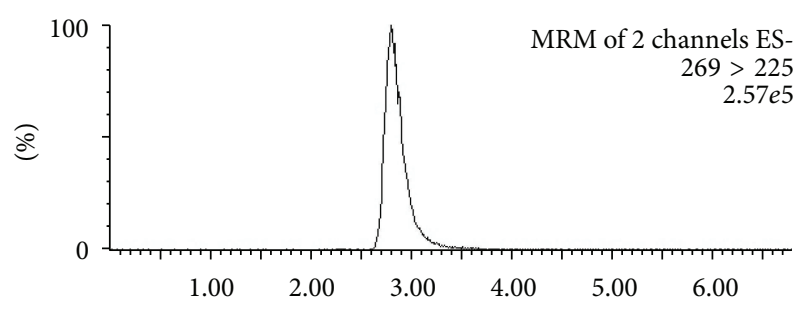

(b)

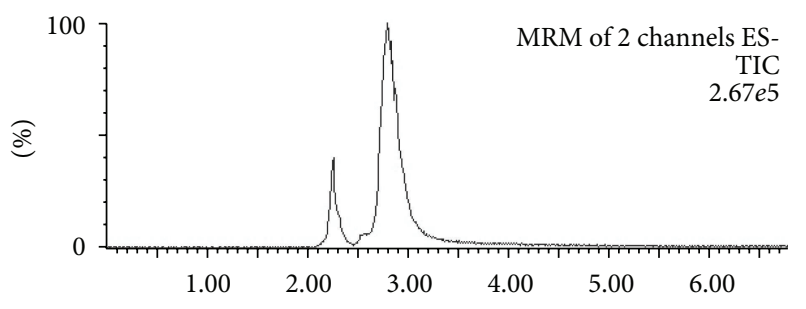

(c)

FIgURE 2: Multiple reaction monitoring chromatograms of rutin and the internal standard. The retention times were 2.25 and $2.85 \mathrm{~min}$ for rutin and IS (emodin), respectively, using reverse-phase HPLC with a mobile phase consisting of $0.1 \%$ acetic acid/acetonitrile $(20: 80$, v/v). (a) Chromatogram for rutin; (b) chromatogram for emodin; (c) chromatogram for both rutin and emodin.

hydrolysis with $\beta$-glucuronidase. After $2 \mathrm{~h}$ of incubation, the concentration of glucuronidated rutin had increased about 6 -fold compared with the first $10 \mathrm{~min}(6.75 \pm 1.73$ versus $37.26 \pm 4.61 \mathrm{nmol} / \mathrm{L} \cdot \mathrm{mg} \cdot$ protein, $P<0.001, n=7)$, but there is no difference between $2 \mathrm{~h}$ and $6 \mathrm{~h}$ of incubation (37.26 \pm 4.61 versus $42.32 \pm 4.13 \mathrm{nmol} / \mathrm{L} \cdot \mathrm{mg} \cdot$ protein, $P>0.05$, $n=7)$. Approximately $33 \%$ of the rutin was metabolized to glucuronidated rutin, and the intracellular concentration of glucuronidated rutin was much lower than that of parent rutin $(37.26 \pm 3.85$ versus $109.61 \pm 4.81 \mathrm{nmol} / \mathrm{L} \cdot \mathrm{mg} \cdot$ protein, $P<0.05, n=7$; Figure 3(c)).

Next, we tested the hypothesis that some drug transporters such as P-gp and MRPs are involved in the intracellular accumulation of rutin in Caco-2 cells. Cells were incubated with rutin for $2 \mathrm{~h}$ at $37^{\circ} \mathrm{C}$ in the presence of a P-gp-selective inhibitor (verapamil) or MRP inhibitors (MK 571 or cyclosporine). After incubation with $100 \mu \mathrm{M}$ rutin for $2 \mathrm{~h}$, the intracellular concentration of rutin was $109.61 \pm 4.81 \mathrm{nmol} / \mathrm{L} \cdot \mathrm{mg} \cdot$ protein in the absence of inhibitors, but interestingly it was clearly lower $(109.61 \pm 4.81$ versus $59.61 \pm 3.23 \mathrm{nmol} / \mathrm{L} \cdot \mathrm{mg} \cdot$ protein, $P<0.01, n=7)$ in the presence of $10 \mu \mathrm{M}$ verapamil (Figure $3(\mathrm{~d})$ ). The fact that the intracellular accumulation of rutin was significantly decreased after treatment with a P-glycoprotein inhibitor.
TABLE 1: Permeability $\left(P_{\text {app }}\right)$ of polyphenol compounds.

\begin{tabular}{lcr}
\hline Compound & \multicolumn{2}{c}{$P_{\text {app }}\left(\mathrm{cm} \cdot \mathrm{s}^{-1} \cdot 10^{-6}\right)$} \\
& AP to BL & BL to AP \\
\hline Rutin & $10.32 \pm 1.25$ & $17.45 \pm 2.53^{1}$ \\
Glucuronidated rutin & $5.21 \pm 0.32$ & $7.02 \pm 1.31^{2}$ \\
\hline
\end{tabular}

Mean $\pm \mathrm{SD} ; n=6$.

${ }^{1}$ Student's $t$-test: significantly different from the AP to BL direction, $P<0.01$.

${ }^{2}$ Student's $t$-test: significantly different from the AP to BL direction, $P<0.05$.

Intracellular accumulation of rutin was also lower in the presence of $20 \mu \mathrm{M}$ cyclosporine, a selective inhibitor of MRP2 $(109.61 \pm 4.81$ versus $76.18 \pm 5.83 \mathrm{nmol} / \mathrm{L} \cdot \mathrm{mg} \cdot$ protein, $P<$ $0.05, n=7)$. Owing to the inhibitory effect of MK 571 on MRP3, which predominantly mediates drug efflux from the basolateral side $[29,30]$, the intracellular accumulation of rutin was clearly higher in the presence of $20 \mu \mathrm{M}$ MK 571 $(109.61 \pm 4.81$ versus $175.68 \pm 8.19 \mathrm{nmol} / \mathrm{L} \cdot \mathrm{mg} \cdot$ protein, $P<$ $0.05, n=7)$. These results suggested that the intracellular accumulation of rutin could be observed in a time- and dose-dependent manner and was due to the actions of $\beta$ glucuronidase and drug transporters.

3.3. Transport Characteristics of Rutin through Caco-2 Cells. The transport of rutin and its glucuronidated metabolites into Caco-2 cells was monitored in the apical to basolateral direction and from the basolateral to apical direction in the presence or absence of the above-mentioned inhibitors. Such data would help us understand the underlying mechanism of how the parent rutin and glucuronidated rutin were transported across Caco-2 cells in both directions. First, the permeability values of the parent rutin or glucuronidated rutin were calculated for the different directions (Table 1). For parent rutin (Figure 4(a)), the BL to AP transport was much greater than that from AP to BL $(135.23 \pm 5.65$ versus $79.38 \pm 2.79 \mathrm{nmol} / \mathrm{L} \cdot \mathrm{mg}$.protein, $P<0.01, n=7)$. For glucuronidated rutin, we observed different rates of transport in both directions $(35.43 \pm 3.21 \mathrm{nmol} / \mathrm{L} \cdot \mathrm{mg} \cdot$ protein, $\mathrm{BL}$ to $\mathrm{AP}$, versus $27.12 \pm 1.34 \mathrm{nmol} / \mathrm{L} \cdot \mathrm{mg} \cdot \mathrm{protein}, \mathrm{AP}$ to BL, $P<0.05, n=7$ ), indicating that the permeability value was also dependent on the direction (Figure 4(b)). Verapamil significantly increased the AP to BL transport of rutin $(139.45 \pm 7.23$ versus $79.38 \pm 2.79 \mathrm{nmol} / \mathrm{L} \cdot \mathrm{mg} \cdot$ protein, $P<0.01, n=7)$ but decreased the BL to AP transport $(68.46 \pm 3.28$ versus135.23 $\pm 5.65 \mathrm{nmol} / \mathrm{L} \cdot \mathrm{mg} \cdot$ protein, $P<$ $0.01, n=7)$. Cyclosporine also significantly increased the AP to BL transport of rutin $(99.36 \pm 1.15$ versus $79.38 \pm$ $2.79 \mathrm{nmol} / \mathrm{L} \cdot \mathrm{mg} \cdot$ protein, $P<0.05, n=7)$ but decreased the $\mathrm{BL}$ to $\mathrm{AP}$ transport $(103.23 \pm 4.53$ versus $135.23 \pm$ $5.65 \mathrm{nmol} / \mathrm{L} \cdot \mathrm{mg} \cdot$ protein, $P<0.01, n=7)$. After incubation with MK 571, which inhibits MRP3 on the basolateral side, the AP to BL transport of rutin also decreased significantly $(43.27 \pm 2.18$ versus $79.38 \pm 2.79 \mathrm{nmol} / \mathrm{L} \cdot \mathrm{mg} \cdot$ protein, $P<$ $0.01, n=7)$ and increased in the BL to AP direction $(153.75 \pm 5.66$ versus $135.23 \pm 5.65 \mathrm{nmol} / \mathrm{L} \cdot \mathrm{mg} \cdot$ protein, $P<0.05, n=7)$. 


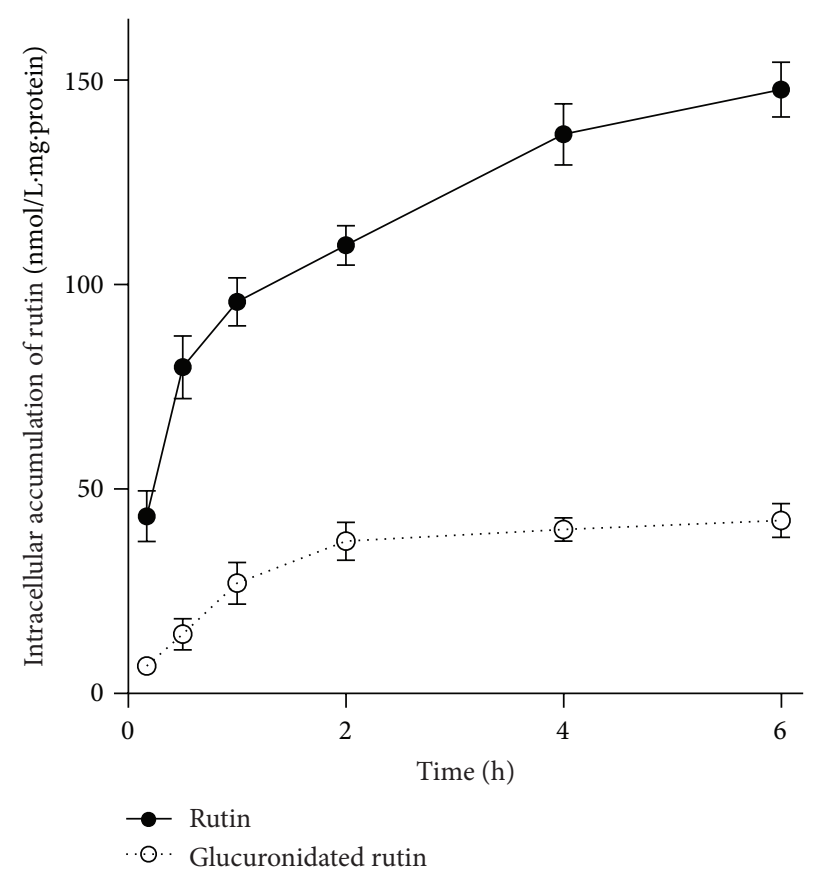

(a)

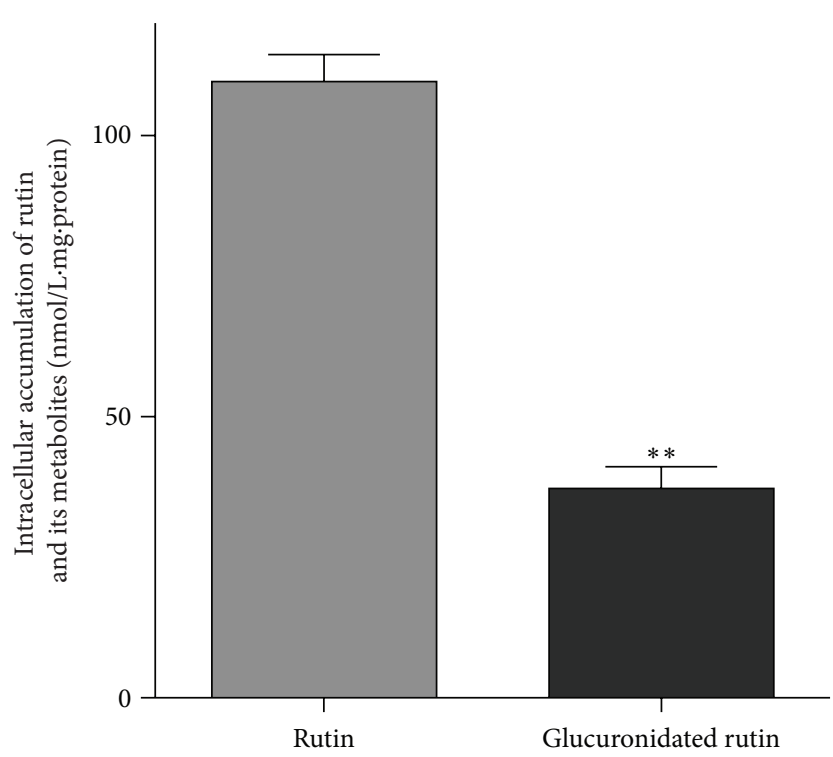

(c)

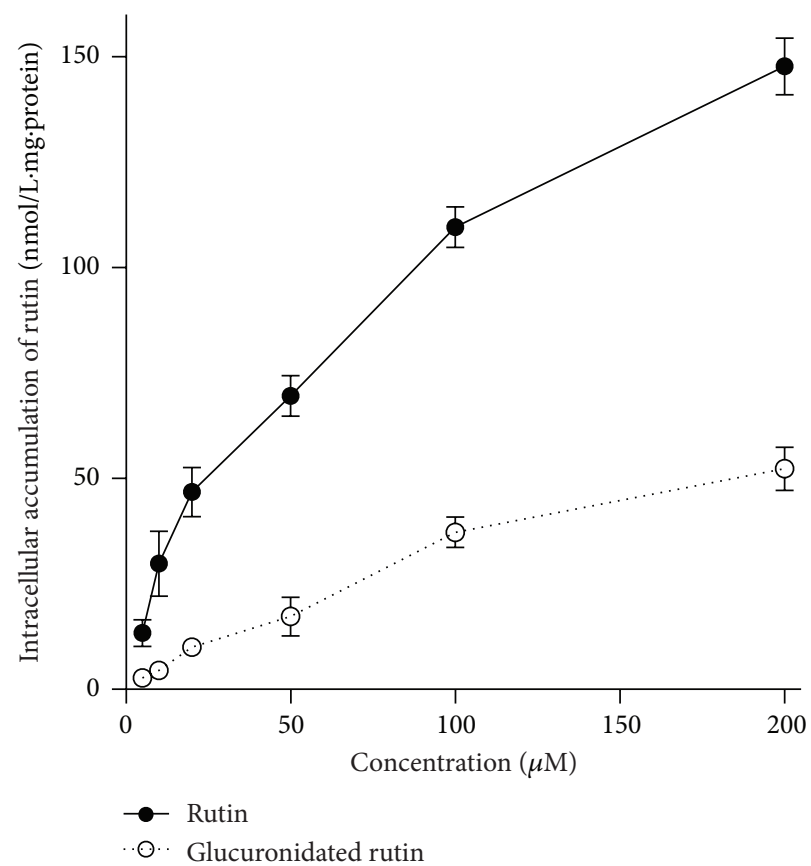

(b)

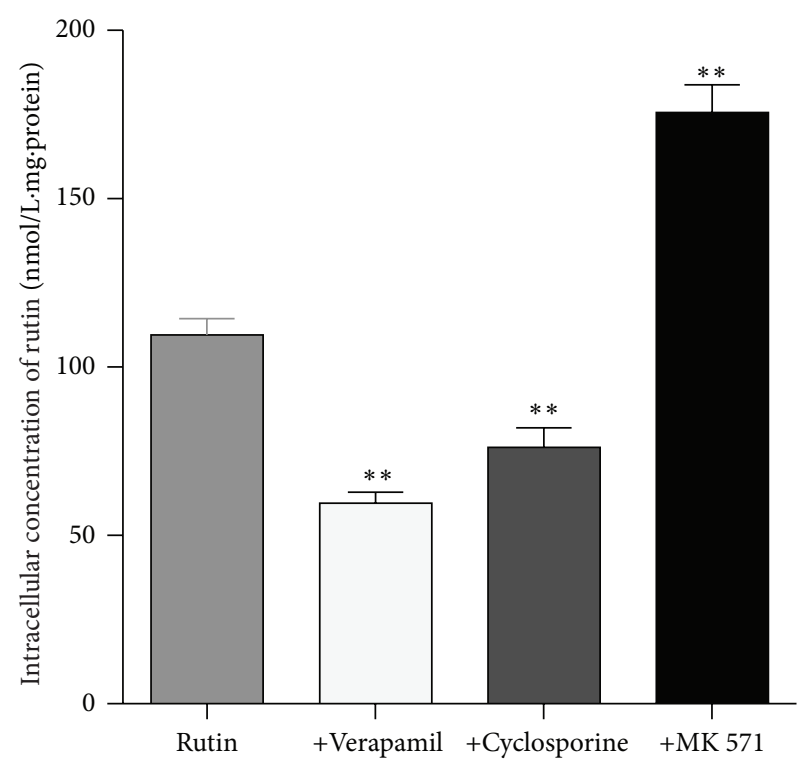

(d)

Figure 3: Absorption of rutin in Caco-2 Cells. (a) Time-dependent intracellular accumulation of rutin and its metabolites at $37^{\circ} \mathrm{C}$ from $10 \mathrm{~min}$ to $6 \mathrm{~h}$. (b) Dose-dependent absorption of rutin and its metabolites at $37^{\circ} \mathrm{C}$ from 5 to $200 \mu \mathrm{M}$. (c) Intracellular accumulation of rutin and its metabolites after incubation with $100 \mu \mathrm{M}$ rutin for $2 \mathrm{~h}$. (d) Intracellular accumulation of rutin in the presence of different inhibitors (10 $\mu \mathrm{M}$ verapamil, $20 \mu \mathrm{M}$ cyclosporine, $20 \mu \mathrm{M}$ MK 571, respectively). Each value is the mean \pm the SD of seven determinations. Statistical significance: ${ }^{* *} P<0.01 ;{ }^{*} P<0.05$.

\section{Discussion}

To the best of our knowledge, this is the first study to examine the characteristics of absorption, transport, and metabolism of rutin into Caco- 2 cells and to also pursue the underlying mechanism. Our novel findings are as follows: (1) intracellular accumulation of rutin was observed in a time- and dosedependent manner in Caco-2 cells; (2) parent rutin was partly metabolized to glucuronidated rutin in Caco-2 cells; (3) the permeability values of parent rutin were different in the two opposite directions, and the amount of glucuronidated rutin transported was dependent on the direction; (4) P-gp and MRP were involved in the intracellular accumulation and transport by Caco-2 cells. These data suggest that rutin can cross the intestinal epithelium via processes mediated by metabolic enzymes and drug transporters. 


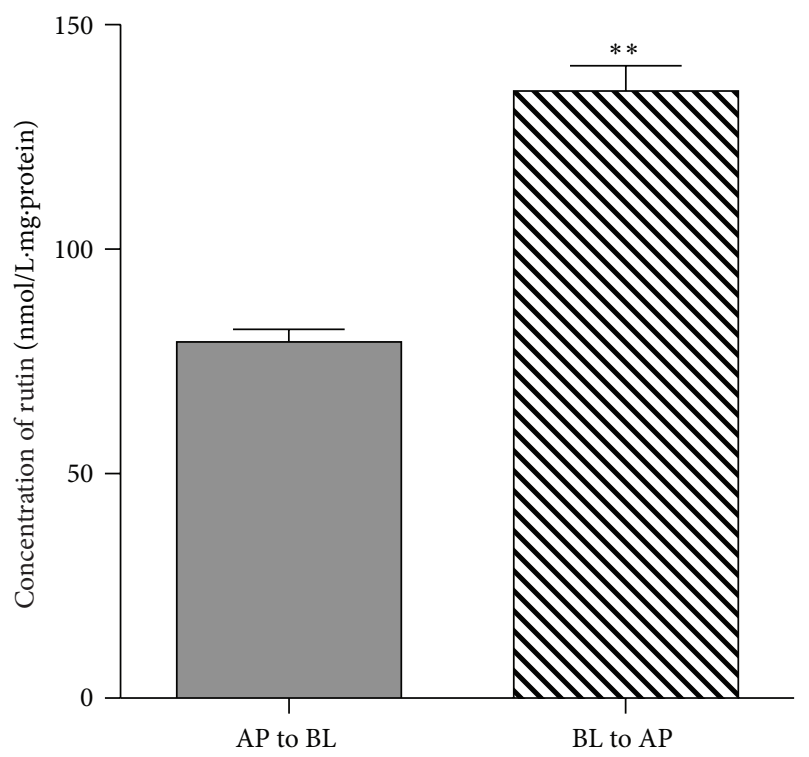

(a)

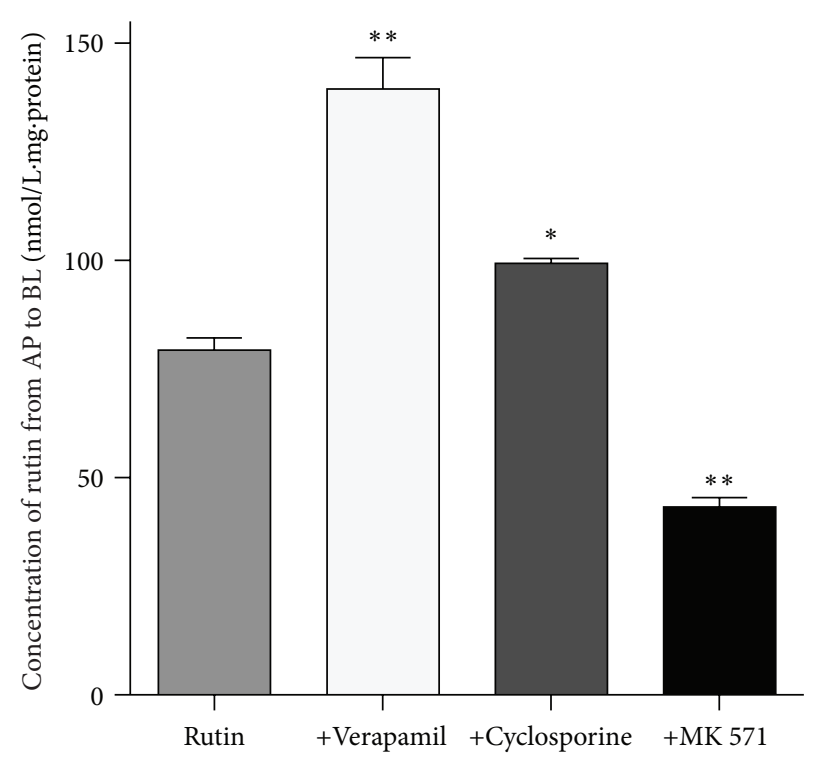

(c)

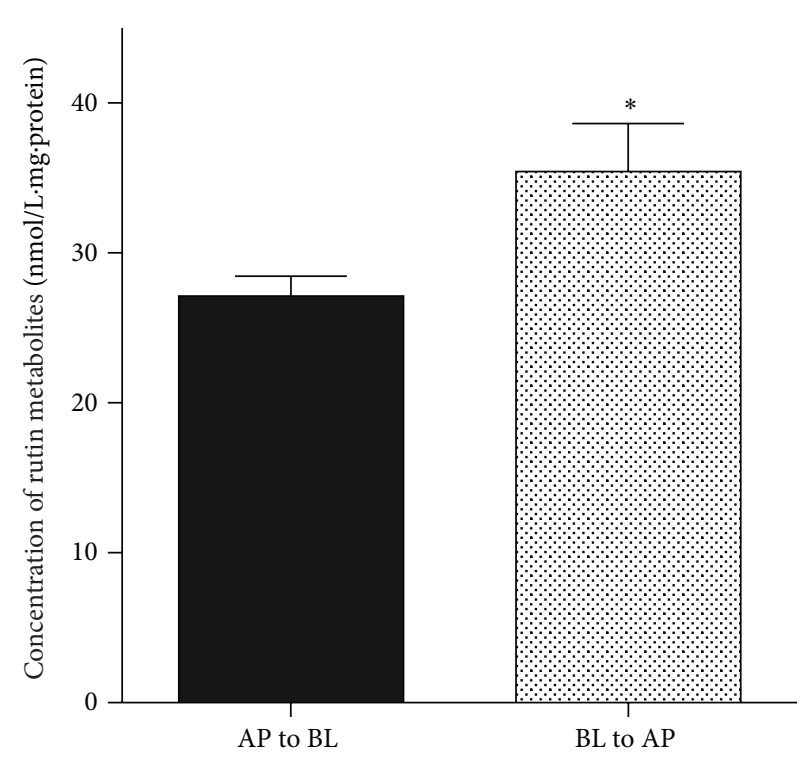

(b)

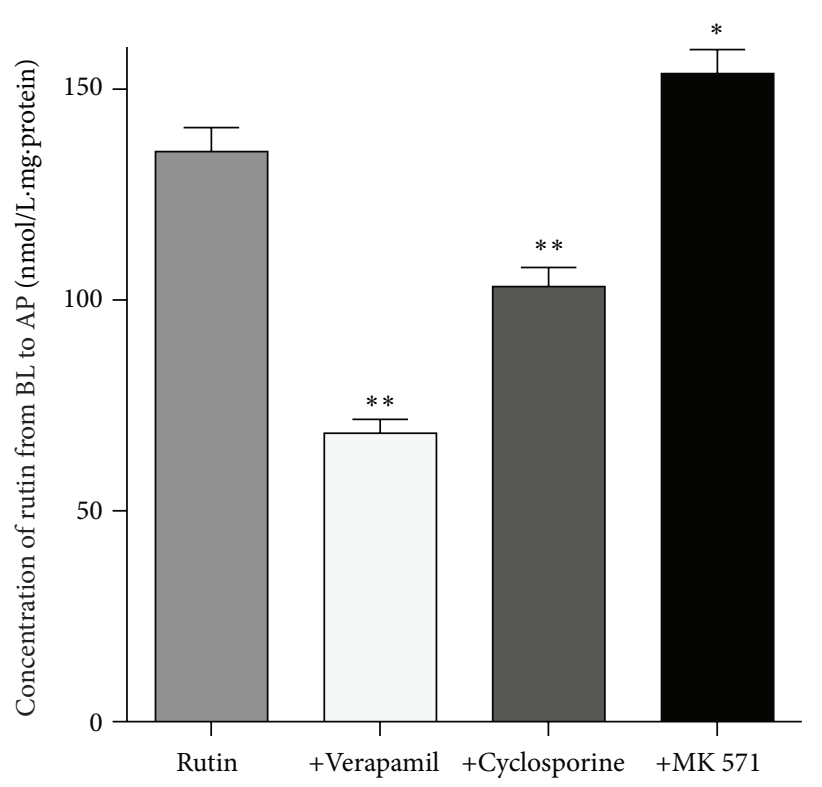

(d)

FIgure 4: Transport of rutin in Caco-2 Cells. (a) Differences in transport of rutin between the AP to BL direction and the BL to AP direction. (b) Difference in transport of glucuronidated rutin between the AP to BL direction and the BL to AP direction. (c) Transport of rutin in the AP to BL direction in the presence of different inhibitors. (d) Transport of rutin in the BL to AP direction in the presence of different inhibitors. Each value is the mean \pm the $\mathrm{SD}$ of seven determinations. Statistical significance: ${ }^{* *} P<0.01 ;{ }^{*} P<0.05$.

Recent studies have shown that a diet enriched in plant polyphenols correlates with lower incidence of hormonerelated cancers and cardiovascular and neurodegenerative diseases. Such a diet also reduces the occurrence of inflammation as well as viral and bacterial infections [31, 32]. Rutin is widely available as a dietary supplement in pharmacies and health food stores. Although much evidence has shown that rutin positively affects human health, the characteristics of its intestinal absorption and metabolism, especially the underlying mechanisms, are still not clear.
Although Caco-2 cells are derived from human colonic adenocarcinoma, the characteristics of expression of P-gp, MRP2, and MRP3 in these cells permit evaluation of the intestinal absorption and transport of natural products and reflect processes that occur in normal intestinal epithelium [30, 33]. Furthermore, Caco-2 cells also express drugmetabolizing enzymes such as glucuronyl or sulfate transferase [34, 35]. Thus, to address the issue of absorption and transport of rutin in the current study, we developed sensitive and reliable analytical methods that were also useful 
for gaining insight into the mechanism governing these processes in human Caco-2 cells, which are widely accepted as a model of human intestinal absorption.

P-gp, which transports hydrophobic drugs out of cells in an ATP-dependent manner, is highly expressed in the brain, liver, intestine, kidney, and placental tissues. P-gp transports drugs and xenobiotic compounds ingested with food from the apical side of intestinal epithelial cells, thus modulating the intestinal absorption of xenobiotic compounds $[10,36]$. To test the effects of integral membrane transporters on rutin absorption and transport, inhibition experiments were performed to investigate the intracellular accumulation of rutin in the absence or presence of verapamil and cyclosporine, inhibitors of P-gp and various MRPs, respectively. The intracellular accumulation of rutin clearly decreased after pretreatment with verapamil and cyclosporine, indicating that the intracellular accumulation and transport processes of rutin in intestinal epithelial cells are regulated by these transporters. Based on the results, P-gp, which is an efflux transporter, not only exports the parent rutin to the apical side but also sequesters metabolites in the cytoplasm and then pumps them out once the complex merges into the cell membrane. Such an efflux pump protects the sensitive areas of the body from xenotoxins present in our diet.

In addition, MRP2 mediates the cellular export of phase II conjugates from the liver, intestine, and kidneys. Moreover, owing to the high expression of MRP2 in the intestinal tract $[37,38]$, we hypothesized that MRP2 is involved in the cellular excretion of phase II conjugates of rutin. This hypothesis is supported by the fact that the permeability values of glucuronidated rutin were lower in the AP to the BL direction than in the opposite direction. The data also showed that rutin was extensively metabolized to glucuronidated rutin by phase II enzymes after incubation with Caco- 2 cells for $1 \mathrm{~h}$.

Our results suggest that P-gp and MRP2, which are localized in the apical and basolateral membranes, are capable of exporting rutin, effectively opposing its absorption and intracellular accumulation. It is important that the toxicity of applied rutin decreases because intestinal P-gp and MRP reduce rutin absorption. Drug-drug interactions will unpredictably affect the toxicity of rutin if rutin is coadministered with other P-gp or MRP inhibitors. Information regarding the functional characteristics of drug transporters is important for improving drug design and delivery by considering possible interactions with specific transporter proteins. Our data show that MRP2 and MRP3 differentially modulate the absorption and transport of rutin and its metabolites owing to the differential distribution of these transporters in the apical and basolateral membranes. The balance between different subtypes of MRPs and P-gp may affect the absorption of rutin in Caco-2 cells. Such balance may favor efflux by P-gp and MRP2, or it may shift to favor influx by MRP3.

\section{Conclusion}

Rutin was pumped out of the cells by P-gp and MRP or metabolized by a phase II metabolic enzyme such as glucuronyl transferase in Caco-2 cells. Glucuronyl transferase may play an important role in drug accumulation, transport, and phase II metabolism in the human intestine. Elucidation of the mechanism of intestinal absorption of rutin will assist the development of highly efficient and absorbable drugs based on the original rutin structure. In addition, detailed information about transporter functions may be important for clarifying possible drug-drug interactions. We show that a specific transport system mediates rutin movement across the apical membrane in Caco- 2 cells. Thus, strategic administration of intestinal P-gp or a MRP inhibitor may improve the therapeutic effect of orally administered rutin.

\section{Conflict of Interests}

The authors declared that they have no conflict of interests exist.

\section{References}

[1] F. Visioli, C. A. de la Lastra, C. Andres-Lacueva et al., "Polyphenols and human health: a prospectus," Critical Reviews in Food Science and Nutrition, vol. 51, no. 6, pp. 524-546, 2011.

[2] T. Magrone and E. Jirillo, "Potential application of dietary polyphenols from red wine to attaining healthy ageing," Current Topics in Medicinal Chemistry, vol. 11, no. 14, pp. 1780-1796, 2011.

[3] M. Asensi, A. Ortega, S. Mena, F. Feddi, and J. M. Estrela, "Natural polyphenols in cancer therapy," Critical Reviews in Clinical Laboratory Sciences, vol. 48, no. 5-6, pp. 197-216, 2011.

[4] F. Visioli and A. Davalos, "Polyphenols and Cardiovascular disease: a critical summary of the evidence," Mini-Reviews in Medicinal Chemistry, vol. 11, no. 14, pp. 1186-1190, 2011.

[5] N. Kamalakkannan and P. S. M. Prince, "Antihyperglycaemic and antioxidant effect of rutin, a polyphenolic flavonoid, in streptozotocin-induced diabetic wistar rats," Basic and Clinical Pharmacology and Toxicology, vol. 98, no. 1, pp. 97-103, 2006.

[6] C. D. Wu, "Grape products and oral health," Journal of Nutrition, vol. 139, pp. 1818S-1823S, 2009.

[7] S. Sumbul, M. A. Ahmad, M. Asif, and M. Akhtar, "Role of phenolic compounds in peptic ulcer: an overview," Journal of Pharmacy and Bioallied Sciences, vol. 3, no. 3, pp. 361-367, 2011.

[8] B. Wu, K. Kulkarni, S. Basu, S. Zhang, and M. Hu, "First-pass metabolism via UDP-glucuronosyltransferase: a barrier to oral bioavailability of phenolics," Journal of Pharmaceutical Sciences, vol. 100, no. 9, pp. 3655-3681, 2011.

[9] C. S. Yang, S. Sang, J. D. Lambert, and M.-J. Lee, "Bioavailability issues in studying the health effects of plant polyphenolic compounds," Molecular Nutrition and Food Research, vol. 52, no. 1, pp. S139-S151, 2008.

[10] R. A. J. Darby, R. Callaghan, and R. M. McMahon, "P-glycoprotein inhibition: the past, the present and the future," Current Drug Metabolism, vol. 12, no. 8, pp. 722-731, 2011.

[11] T. Sakaeda, "MDR1 genotype-related pharmacokinetics: fact or fiction?" Drug Metabolism and Pharmacokinetics, vol. 20, no. 6, pp. 391-414, 2005.

[12] E. M. Wright, D. D. Loo, and B. A. Hirayama, "Biology of human sodium glucose transporters," Physiological Reviews, vol. 91, no. 2, pp. 733-794, 2011.

[13] I. Ieiri, "Functional significance of genetic polymorphisms in Pglycoprotein (MDR1, ABCB1) and breast cancer resistance protein (BCRP, ABCG2)," Drug Metabolism and Pharmacokinetics, vol. 27, no. 1, pp. 85-105, 2012. 
[14] A. I. Alvarez, R. Real, M. Pérez, G. Mendoza, J. G. Prieto, and G. Merino, "Modulation of the activity of ABC transporters (Pglycoprotein, MRP2, BCRP) by flavonoids and drug response," Journal of Pharmaceutical Sciences, vol. 99, no. 2, pp. 598-617, 2010.

[15] B. Marquez and F. van Bambeke, "ABC multidrug transporters: target for modulation of drug pharmacokinetics and drug-drug interactions," Current Drug Targets, vol. 12, no. 5, pp. 600-620, 2011.

[16] N. Melaine, M.-O. Liénard, I. Dorval, C. Le Goascogne, H. Lejeune, and B. Jégou, "Multidrug resistance genes and P-glycoprotein in the testis of the rat, mouse, guinea pig, and human," Biology of Reproduction, vol. 67, no. 6, pp. 1699-1707, 2002.

[17] D. A. Volpe, "Drug-permeability and transporter assays in Caco-2 and MDCK cell lines," Future Medicinal Chemistry, vol. 3, no. 16, pp. 2063-2077, 2011.

[18] C. Calhau, F. Martel, C. Hipólito-Reis, and I. Azevedo, "Modulation of uptake of organic cationic drugs in cultured human colon adenocarcinoma Caco- 2 cells by an ecto-alkaline phosphatase activity," Journal of Cellular Biochemistry, vol. 87, no. 4, pp. 408-416, 2002.

[19] L. Smetanová, V. Stětinová, Z. Svoboda et al., "Caco-2 cells, biopharmaceutics classification system (BCS) and biowaiver," Acta Medica, vol. 54, pp. 3-8, 2011.

[20] A. Crowe and C. Wright, "The impact of P-glycoprotein mediated efflux on absorption of 11 sedating and less-sedating antihistamines using Caco-2 monolayers," Xenobiotica, vol. 42, no. 6, pp. 538-549, 2012.

[21] K. Ikeda, M. Myotoku, and Y. Hirotani, "Characterization of multidrug resistance-associated protein mRNAs expression profiles in Caco-2 and HT-1080 cell lines induced by methotrexate," Pharmazie, vol. 63, no. 12, pp. 883-889, 2008.

[22] A. Lampen, B. Ebert, L. Stumkat, J. Jacob, and A. Seidel, "Induction of gene expression of xenobiotic metabolism enzymes and $\mathrm{ABC}$-transport proteins by $\mathrm{PAH}$ and a reconstituted $\mathrm{PAH}$ mixture in human Caco-2 cells," Biochimica et Biophysica Acta, vol. 1681, no. 1, pp. 38-46, 2004.

[23] A. Alhamoruni, A. C. Lee, K. L. Wright, M. Larvin, and S. E. O'Sullivan, "Pharmacological effects of cannabinoids on the Caco-2 cell culture model of intestinal permeability," Journal of Pharmacology and Experimental Therapeutics, vol. 335, no. 1, pp. 92-102, 2010.

[24] J. B. Vaidyanathan and T. Walle, "Cellular uptake and efflux of the tea flavonoid (-)-epicatechin-3-gallate in the human intestinal cell line Caco-2," Journal of Pharmacology and Experimental Therapeutics, vol. 307, no. 2, pp. 745-752, 2003.

[25] J. M. Young and M. E. Morris, "Pharmacokinetics and bioavailability of the bioflavonoid biochanin A: effects of quercetin and EGCG on biochanin A disposition in rats," Molecular Pharmaceutics, vol. 4, no. 6, pp. 865-872, 2007.

[26] Q. Ma, E.-Y. Kim, and O. Han, "Bioactive dietary polyphenols decrease heme iron absorption by decreasing basolateral iron release in human intestinal Caco-2 cells," Journal of Nutrition, vol. 140, no. 6, pp. 1117-1121, 2010.

[27] J. Bielawski, Z. M. Szulc, Y. A. Hannun, and A. Bielawska, "Simultaneous quantitative analysis of bioactive sphingolipids by high-performance liquid chromatography-tandem mass spectrometry," Methods, vol. 39, no. 2, pp. 82-91, 2006.

[28] Z. Teng, C. Yuan, F. Zhang et al., "Intestinal absorption and first-pass metabolism of polyphenol compounds in rat and their transport dynamics in caco-2 cells," PLoS ONE, vol. 7, no. 1, Article ID e29647, 2012.
[29] K. de van Wetering, A. Burkon, W. Feddema et al., "Intestinal breast cancer resistance protein (BCRP)/Bcrpl and multidrug resistance protein 3 (MRP3)/Mrp3 are involved in the pharmacokinetics of resveratrol," Molecular Pharmacology, vol. 75, no. 4, pp. 876-885, 2009.

[30] X. Ming, B. M. Knight, and D. R. Thakker, "Vectorial transport of fexofenadine across Caco-2 cells: involvement of apical uptake and basolateral efflux transporters," Molecular Pharmaceutics, vol. 8, no. 5, pp. 1677-1686, 2011.

[31] D. Stagos, G. Amougias, A. Matakos, A. Spyrou, A. M. Tsatsakis, and D. Kouretas, "Chemoprevention of liver cancer by plant polyphenols," Food and Chemical Toxicology, vol. 50, no. 6, pp. 2155-2170, 2012.

[32] E. M. Varoni, G. Lodi, A. Sardella, A. Carrassi, and M. Iriti, "Plant polyphenols and oral health: old phytochemicals for new fields," Current Medicinal Chemistry, vol. 19, no. 11, pp. 17061720, 2012.

[33] H. Sun, E. C. Y. Chow, S. Liu, Y. Du, and K. S. Pang, "The Caco-2 cell monolayer: usefulness and limitations," Expert Opinion on Drug Metabolism and Toxicology, vol. 4, no. 4, pp. 395-411, 2008.

[34] E. F. A. Brandon, T. M. Bosch, M. J. Deenen et al., "Validation of in vitro cell models used in drug metabolism and transport studies; Genotyping of cytochrome P450, phase II enzymes and drug transporter polymorphisms in the human hepatoma (HepG2), ovarian carcinoma (IGROV-1) and colon carcinoma (CaCo-2, LS180) cell lines," Toxicology and Applied Pharmacology, vol. 211, no. 1, pp. 1-10, 2006.

[35] J. Borlak and C. Zwadlo, "Expression of drug-metabolizing enzymes, nuclear transcription factors and $\mathrm{ABC}$ transporters in Caco-2 cells," Xenobiotica, vol. 33, no. 9, pp. 927-943, 2003.

[36] K. Naruhashi, Y. Kurahashi, Y. Fujita et al., "Comparison of the expression and function of ATP binding cassette transporters in Caco-2 and T84 cells on stimulation by selected endogenous compounds and xenobiotics," Drug Metabolism and Pharmacokinetics, vol. 26, no. 2, pp. 145-153, 2011.

[37] C. Hilgendorf, G. Ahlin, A. Seithel, P. Artursson, A.-L. Ungell, and J. Karlsson, "Expression of thirty-six drug transporter genes in human intestine, liver, kidney, and organotypic cell lines," Drug Metabolism and Disposition, vol. 35, no. 8, pp. 1333-1340, 2007.

[38] S. Berggren, C. Gall, N. Wollnitz et al., "Gene and protein expression of P-glycoprotein, MRP1, MRP2, and CYP3A4 in the small and large human intestine," Molecular Pharmaceutics, vol. 4, no. 2, pp. 252-257, 2007. 

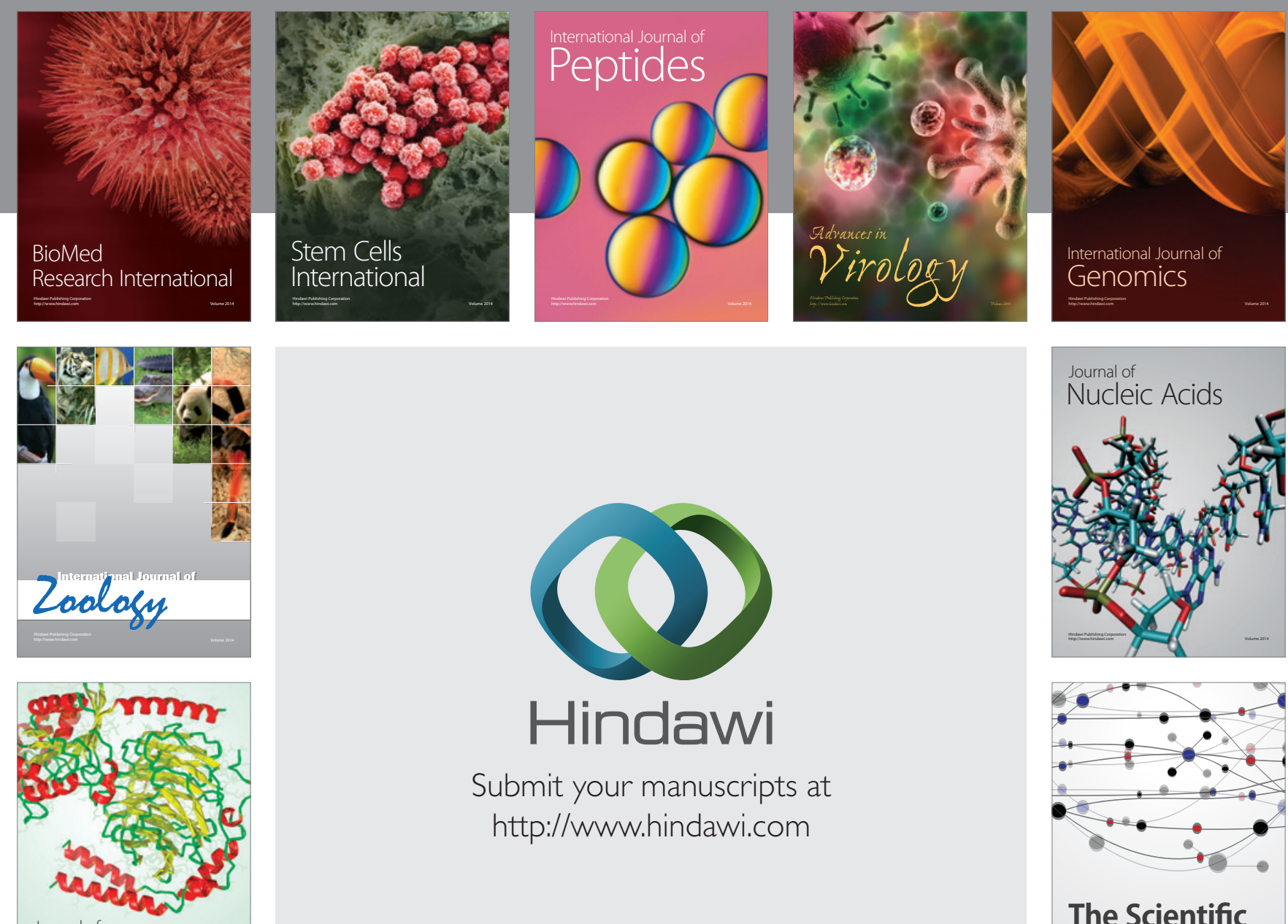

Submit your manuscripts at

http://www.hindawi.com

Journal of
Signal Transduction
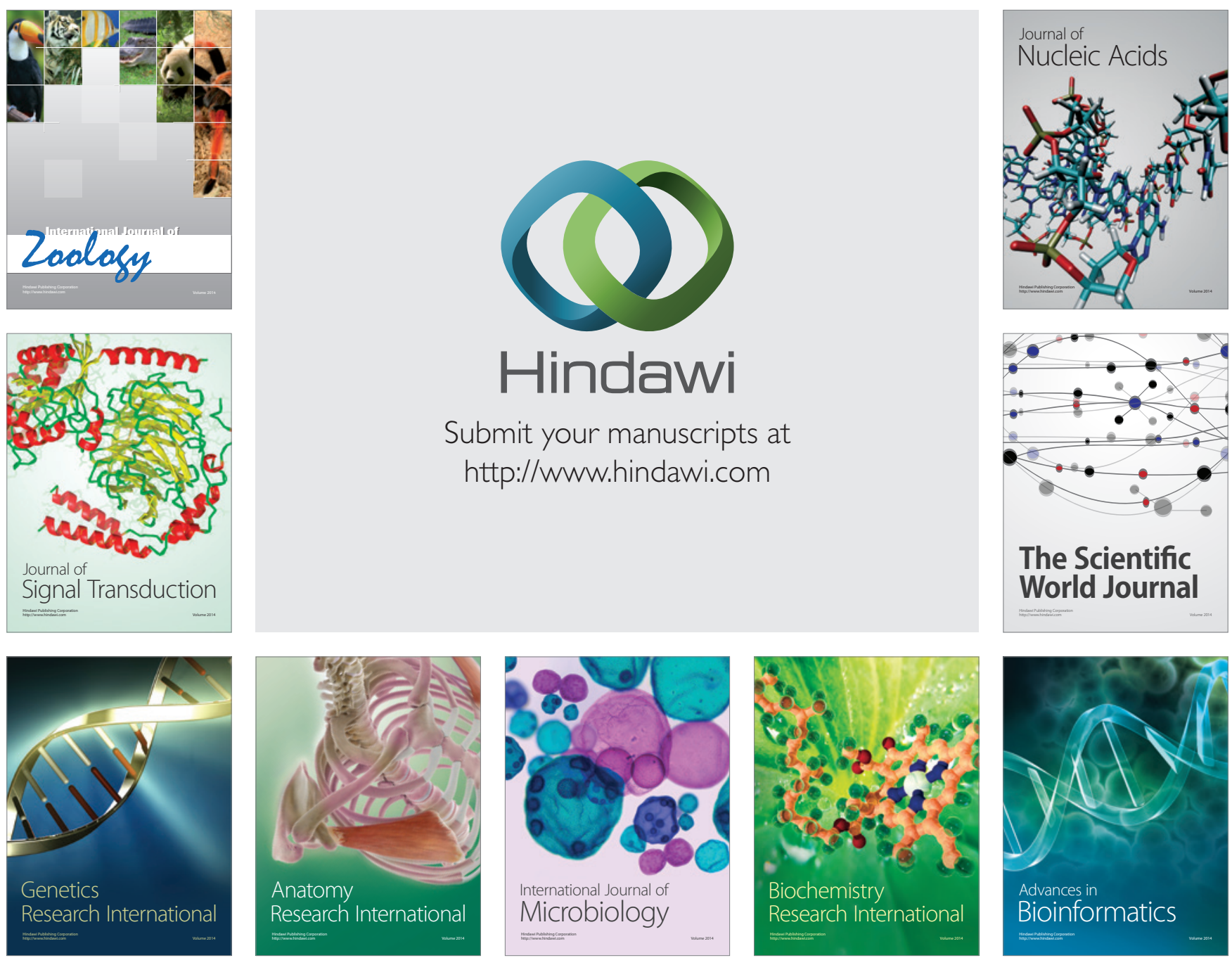

The Scientific World Journal
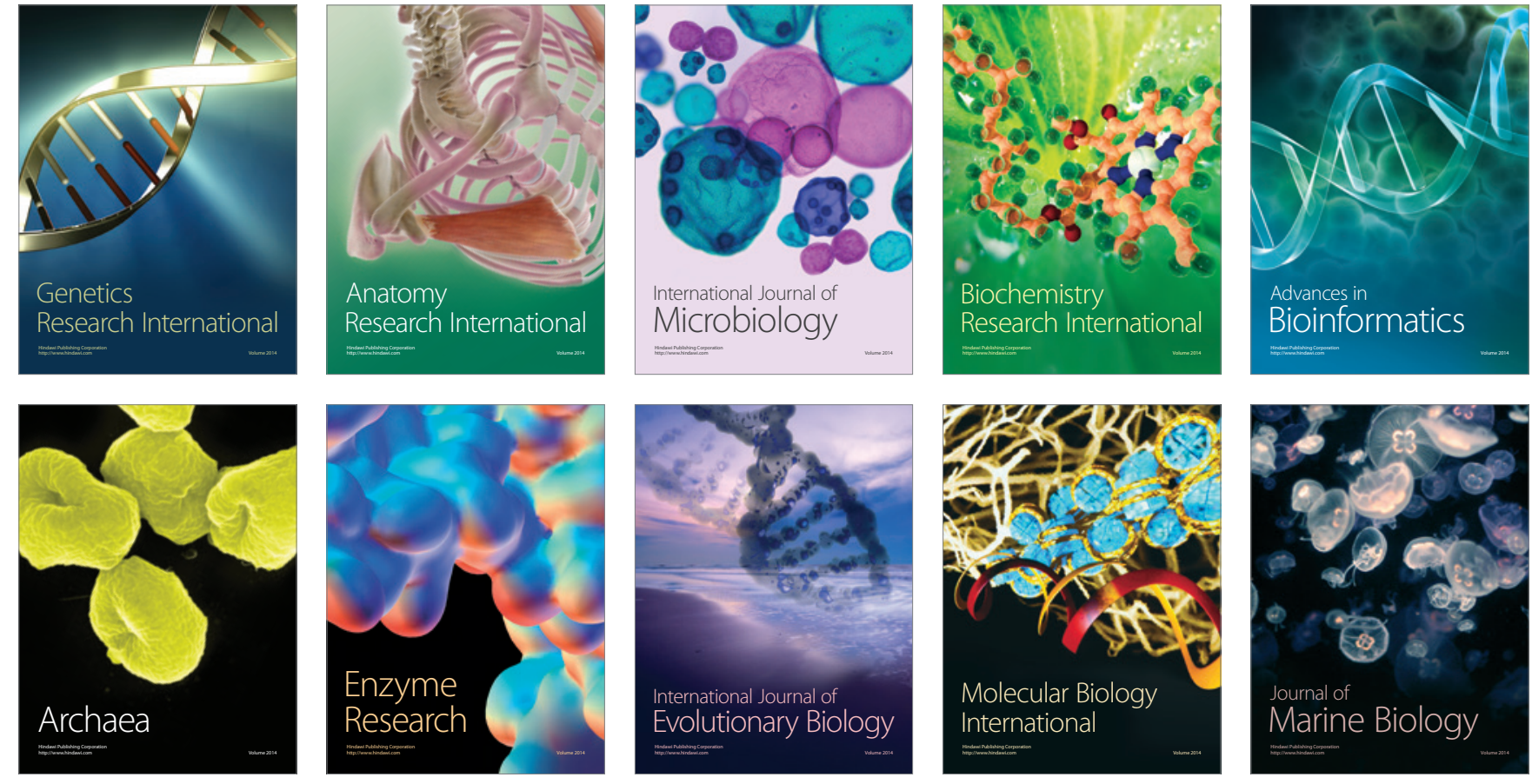